\title{
Pragmatic Language Disorders Resulting from Semantic Degradation in Patients with Alzheimer's Disease
}

\author{
Bertug Sakin \\ University of Health Sciences, Hamidiye Faculty of Health Sciences, Department of Speech and Language Therapy, Istanbul, Turkey. \\ Correspondence Author: Bertug Sakin \\ E-mail: bertug.sakin@sbu.edu.tr \\ Received: $15.12 .2020 \quad$ Accepted: 09.02 .2021
}

\begin{abstract}
Objective: The aim of this study is to create an inventory of pragmatic language disorders specific to Alzheimer's disease (AD), to illustrate them by case examples, to determine the severity of disorders according to the stages of Alzheimer's, and to specify the impact of patients' demographic characteristics on the pragmatic disorders experienced by them.

Methods: The study adopted a descriptive research design. The sample was selected using the stratified sampling method. Interviews were conducted with the patients using the free association technique. The feedbacks from the participants were collected as audio recordings and transcribed using the SALT program. The findings were analysed and compared with the control group data, and the conclusion was drawn from the results obtained.

Results: In the course of study 19 types of pragmatic language disorders of AD patients were identified. The differences between the pragmatic disorders detected at various stages of the disease were illustrated in detail using case examples, and the effect of the demographic variables on the disorders was determined.

Conclusion: As a result of the research, pragmatic language disorders resulting from semantic degradation experienced by AD patients were identified. It was found out that the early stage of $A D$ is characterised by mild pragmatic disorders, which tend to get more distinct at the middle stage and even more severe at the late stage. In addition, it was determined that the demographic characteristics of patients have an impact on the severity of pragmatic language disorders.
\end{abstract}

Keywords: Dementia, Alzheimer's disease, semantic degradation, pragmatic language disorders.

\section{INTRODUCTION}

The American Psychiatric Association describes dementia as being a complex of mental and behavioural disorders, comprising one or more executive dysfunctions such as aphasia, apraxia, and agnosia, and exhibiting clinical features such as memory impairment $(1,2)$.

The most common type of dementia is Alzheimer's disease $(A D)$, corresponding to about $60 \%$ of cases $(3,4)$. $A D$, characterized by cognitive dysfunctions, is a progressive neurodegenerative disease (5). The most prominent feature of $A D$ is forgetfulness observed from the very beginning of the disease (6). Neuropathological changes in AD include senile plaques formed by deposits of diffuse extracellular amyloid, intracellular neurofibrillary tangles, reactive microgliosis and neuron-synapse losses $(7,8)$.

Post-mortem macroscopic examination of the brains of individuals with $A D$ reveals such neuropathological features as cortical atrophy and enlarged ventricles and sulci (9). In the late stages of $A D$ the degeneration spreads from temporal association cortex to the parietal cortex, and from there to the frontal cortex and eventually to other areas of the neocortex (10). In the prodromal phase patients with mild cognitive disorders usually have no functional impairment, however since neurodegeneration affects the large-dimensional neurocognitive network of episodic memory, the patient has a progressive memory impairment that can be detected by neuropsychological methods (11).

Language disorders occurring in $A D$ patients are closely related to the impairment of such functions as memory, attention and abstraction, and they show themselves at an early, middle or late stage depending on the course of the disease. These linguistic disorders also reveal extremely important findings in terms of diagnosing clinical subtypes of dementia $(12,13)$. In the early stages of the disease, individuals usually have fluent speech. Articulation disorders, breakdown of the syntactic structure of language as well as auditory processing disorders and difficulties when reading 
out loud do not fully manifest themselves at this stage (14). Symptoms related to language disorders in the early stages of $A D$ include difficulties with object and action naming, word recalling and finding the correct word. The middle stage is characterised by patients not being able to syllabify and find the appropriate words during communication. This situation shows the loss of conceptual basic perception and abstract information in patients. In the late stages of the disease, the impairment in language functions becomes more severe (6,15-18).

In the early stages of $A D$, pragmatic language disorders are not much evident. However, as the disease progresses, the symptoms get much more severe and in the last stages of the disease result in the patient's complete loss of the linguistic communication with the outside world (19). The deterioration of the pragmatic component of language in different stages of the disease is closely related to the impairment of explicit memory, which includes episodic and semantic memory, and the loss of the awareness of the distinctive semantic features such as the features and functions of concepts in communication $(20,21)$. As the disease progresses, disconnected speech is observed alongside with the decline in the ability of patients to choose the correct words and use them according to the context (22). Based on these findings, pragmatic language disorders occurring in $A D$ can be said to be the result of semantic memory destruction caused by temporal lobe atrophy experienced by the patient (23-26).

In the light of the facts mentioned above, our research aims at creating a profile of pragmatic language disorders specific to $A D$, making an inventory of these disorders and illustrating them by case examples, determining the severity of disorders according to the stages of $A D$, and specifying the impact of patients' demographic characteristics on the pragmatic disorders experienced by them.

\section{METHODS}

The sample was selected using the 'stratified sampling' method that involves the division of a population into smaller subgroups. After the group that constitutes the population of the study was stratified, the participants were selected from each stratum using a simple random nonproportional stratified sampling method. The study was carried out on 20 patients possessing different demographic characteristics, diagnosed with early, middle and late stages of $A D$, and staying in the $A D$ Department of one of the elderly care centres in Istanbul, and a control group of 20 healthy aging elderly participants with similar demographic characteristics. The study adopted a descriptive research design. The selection and exclusion criteria of the sample group included having been diagnosed with early, middle or late stage of $A D$, being in the age range of at least 65 and at most 95, not having undergone language and speech therapy before, not having severe intelligibility and hearing problems. Control group selection and exclusion criteria are as follows: having similar demographic characteristics with the case group, not having any mental problems, not having language and speech disorders, not having undergone language and speech therapy.

Ethical approval was obtained from the Hamidiye Scientific Research Ethical Committee of University of Health Sciences (Approval number: 20/380). After participants and staff members were informed about the research design and any other related issues, question sets related to 'professions, clothes, household items, seasons and food' to be used in the interview were created. Interviews were conducted with the patients using free association technique in order to obtain natural verbal feedback from them. In addition, pictures containing visuals related to the question sets were shown to the patients and the answers of the participants were collected in the form of audio recordings. The audio recordings were transcribed using the 'Systematic Analysis of Language Transcripts (SALT)' program without adding or removing anything. After analysing the obtained written texts, an inventory of pragmatic language disorders caused by semantic degradation was created and the differences between these disorders according to the stages and demographic characteristics of the patients were illustrated by case examples.

\section{RESULTS}

Pragmatic language disorders caused by semantic degradation experienced by $A D$ patients, which were detected within the scope of the study, were as follows:

\subsection{Inability to Understand and Use Abstract Language}

$1^{\text {st }}$ stage AD patient T.S. said, "İçi sizi, içi beni, içi beni dışı sizi yakıyor" (tries to reproduce the saying "Dışı seni, içi beni yakar" - "Good from far, far from good"). $2^{\text {nd }}$ stage AD patient P.S. said, "Oğlumun, çocukları severler, gülü seversin, oğlum, gülü, başına katlanırsın" (tries to reproduce the proverb "Gülü seven dikenine katlanır" - "There's no rose without a thorn"). When told, "I guess you've grown cold towards such people," $3^{\text {rd }}$ stage AD patient Y.E.A said, "hmmm, I haven't, if I'm cold, I'll put on this".

\subsection{Inability to Make up Long Sentences}

When asked, "Do you have children, if any, can you talk about them?" $1^{\text {st }}$ stage AD patient S.S. responded, "Yes, I have children, of course I have". When asked what she was going to do that day, $2^{\text {nd }}$ stage AD patient G.H. responded, "I'm here today. Here". When asked, "What did you do in the garden, how was your day?" $3^{\text {rd }}$ stage AD patient F.Ç. said, "Today? It was good, good".

\subsection{Repetitions}

\section{Perseveration}

When asked about her hometown, $1^{\text {st }}$ stage AD patient Z.T. answered, "Erzurum, Erzurum, Erzurum, are you from 
Erzurum?" $2^{\text {nd }}$ stage AD patient A.S. said, "Yaşar Nuri Öztürk, professor, professor, professor of theology theology". When asked, "Did you eat? Are you hungry?" $3^{\text {rd }}$ stage AD patient L.H. replied, "eat, I ate, I ate, eat, yes".

\section{Echolalia}

When asked "It feels like it's summer, isn't it?" $1^{\text {st }}$ stage $A D$ patient B.B. answered, "It feels like summer, it feels like summer". When asked, "Are you fifty years old?" $2^{\text {nd }}$ stage $A D$ patient G.H replied, "Fifty, fifty, are you fifty, you fifty". When asked, "Where were you born?" $3^{\text {rd }}$ stage AD patient F.C.. responded, "Were born, were born, were born, were born".

\subsection{Inability to Follow a Thread of Conversation}

When asked, "This cat is very nice, is it yours?" $1^{\text {st }}$ stage AD patient S.S. said, "Yes, this cat is very nice, I can speak English, yes I did good translations". When asked, "What's the weather like now?" $2^{\text {nd }}$ stage $A D$ patient A.E. replied "Right now I don't stay there". When asked, "What is there in the room?" $3^{\text {rd }}$ stage AD patient F.Ç. said, "They are not mine, this is hotel, hotel".

\subsection{Lesser Tendency for Clustering Behaviour}

When asked, "What things are brown?" $1^{\text {st }}$ stage AD patient S.S. answered, "A tree", when asked to add anything else, she said, "A tree, a table". When asked, "What other professions are there other than the doctor related to health?" $2^{\text {nd }}$ stage AD patient V.Y. answered, "There is a doctor, there is a nurse, there are those who wear white clothes, in the hospital". When asked, "So what other animals are there in the village?" $3^{\text {rd }}$ stage AD patient F.Ç. responded, "There are sheep, there are animals, running, there are sheep".

\subsection{Being Aware of Having Made a Mistake but Not Being Able to Correct It}

When asked, "Do you like listening to music?" $1^{\text {st }}$ stage AD patient S.S. said, "Yes, I do. Sorry, I don't like so much". When asked if he was married $2^{\text {nd }}$ stage AD patient F.M.N. said that he wasn't. However, when the interviewer noticed that his records said that he was married, the patient replied, "No, no, yes I'm married". When asked, "Do you have a notebook?" $3^{\text {rd }}$ stage AD patient E.I. said, "Here is it, I've brought it from above". After being reminded that it was not his notebook, he still said, "No, no, I've just brought it, I've bought it from inside, l've brought it".

\subsection{Inability to Grasp the Main Idea of the Conversation}

When asked to describe her childhood home, $1^{\text {st }}$ stage $A D$ patient A.Ö. said, "I say, they graduate from their universities. They are not married, that is they are single". When asked if he had any close friends, $2^{\text {nd }}$ stage AD patient V.Y. answered, "I came from there, set off but it took a long time". When asked what her favourite food was, $3^{\text {rd }}$ stage AD patient F.Ç. replied, "I came today today, I'Il go here tomorrow. To Paşabahçe".

\subsection{Inability to Start a Conversation}

After the interview was finished, $1^{\text {st }}$ stage $A D$ patient T.S. asked, "Do you have any other questions?" $2^{\text {nd }}$ stage $A D$ patient E.D. said, "There are red flowers, do you know what their names are?" Patients at the $3^{\text {rd }}$ stage didn't make any attempts to initiate a conversation.

\subsection{Inability to Understand the Question Asked}

When asked, "Are you in pain?" $1^{\text {st }}$ stage AD patient A.Ö. replied, "They don't give any, look here is the hospital, we stay here but they didn't give any". When asked if she read books, $2^{\text {nd }}$ stage AD patient G.H. responded, "If I had a job related to it, I would speak English brilliantly today, but mine was different". When asked how many children she had, $3^{\text {rd }}$ stage AD patient F.Ç. answered, "I was born in thirty-seven, I'm over eighty".

\subsection{Lack of Use of Respectful Language}

While $1^{\text {st }}$ stage AD patient T.S. used respectful language when saying, "My deceased husband was a very kind gentleman, he was a retired teacher" and $2^{\text {nd }}$ stage AD patient P.S. used words like "You're welcome" and "Thank you", patients at the $3^{\text {rd }}$ stage weren't found out to use respectful language.

\subsection{Frequent Use of the Word "Şey" ("Thing", "Um")}

$1^{\text {st }}$ stage AD patient T.S. said, "Inönü did um, um, that is, he criticized that he did not enter the war, he said yes, we were hungry, but we didn't lose our fathers". $2^{\text {nd }}$ stage AD patient G.H. said, "Because since um, that is since 12 years old she has experienced great um, difficulty". $3^{\text {rd }}$ stage AD patient F.Ç. said, "I studied only at primary um, um".

\subsection{Periphrasis}

When asked, "Where does this animal live?" $1^{\text {st }}$ stage $A D$ patient A.Ö. responded, "They have their place. They also have a house. Where they stay, they have a house apart from home". When asked what her job was, $2^{\text {nd }}$ stage $A D$ patient G.H. said, "I do different kind of things, when they ask something I answer, when it is wrong, I correct it, this kind of job you see". When asked if she knew any other neighbourhoods or districts in Istanbul, $3^{\text {rd }}$ stage AD patient F.Ç. said, "It was in Istanbul. The place where our aunt used to live".

\subsection{Paraphasia}

\section{Semantic Paraphasia}

When asked, "So what do you eat the soup with?" $1^{\text {st }}$ stage AD patient A.A. answered, "With fork". When asked if he had an umbrella, $2^{\text {nd }}$ stage AD patient F.M.N. replied, "Umbrella, it is used in summer, umbrella then". When asked, "(by pointing 
the window) What is the name of this?" $3^{\text {rd }}$ stage AD patient S.M. answered, "Door, let's open the door, let the air in".

\section{Neologistic Paraphasia}

When asked, "What did you use in the field?" $1^{\text {st }}$ stage AD patient Z.T. answered, "These are agricultural biği chemicals". When asked, "In which season do we wear warm things?" $2^{\text {nd }}$ stage AD patient G.H. replied, "There is more assulu in winter". When asked, "What do we write in the notebook with?" $3^{\text {rd }}$ stage AD patient S.M. said, "With yeesin".

\subsection{Omitting Words and Predicates in Sentences}

When asked, "Do you like reading?" $1^{\text {st }}$ stage AD patient T.S. answered, "I ... hmm... every book I can get here. When they come to visit the patients, I even ...". $2^{\text {nd }}$ stage AD patient A.E. said, "there was a patient, I would ... him, I would examine him". When asked if she liked to watch movies, patient at the $3^{\text {rd }}$ stage of AD F.Ç. answered, "Very much, I wat..., movies, I wat..." (tries to say the verb "seyretmek" - "watch").

\subsection{Inability to Answer the Question Properly}

When asked, "So what kind of objects are there in the garden?" $1^{\text {st }}$ stage AD patient B.B. answered, "Well that's enough for me, I don't need anything else. I'm not fond of luxury". When asked if she was married, $2^{\text {nd }}$ stage AD patient G.H. replied, "My daughter has 2 children, a son and a daughter, they all went to America". When asked, "Do you know the capital city of Germany?" $3^{\text {rd }}$ stage AD patient E.I. said, "I do not speak German, I went there for the first time, I worked alone, I came back but I did not learn it."

\subsection{Speaking out of Context}

When asked, "Where did you live before?" $1^{\text {st }}$ stage $A D$ patient T.S. answered, "I actually used to live in Ankara. I'm from Izmir, though. My son is a doctor here. I was ill. In 2015 my hip bone was broken. I've had a lot of surgery. After the operation, my children hired a caregiver for me. I lost my wife in 2003, it has been sixteen years". When asked, "Who do you live with here, alone? Or with your wife?" $2^{\text {nd }}$ stage AD patient E.D. replied, "I hate fighting with my wife. We shout at each other, then quickly calm down". When asked, "What would you plant in your field in the village?" $3^{\text {rd }}$ stage AD patient Y.K. said, "Cucumber, tomato, pepper. My mom died. My brother died. My sister died. It's not easy, it's very difficult. May God give no one so much pain, that is, death causes much pain. It never comes out of you again. That's how loneliness is".

\subsection{Inability to Provide Information and Explanations}

No disorder of this kind was observed in $1^{\text {st }}$ stage AD patients participating in the study. When asked, "Why do you think winters are not so cold anymore, especially in Istanbul?" $2^{\text {nd }}$ stage AD patient A.E. replied, "Yes, it is, yeah so the weather is not so much anymore, but it's not cold". When asked to describe her profession, $3^{\text {rd }}$ stage AD patient F.Ç. answered, "Washing like this all the time, doing um like this, my dear".

\subsection{Inappropriate and Incorrect Use of Subjects and Personal Endings}

No disorder of this kind was observed in $1^{\text {st }}$ stage AD patients participating in the study. $2^{\text {nd }}$ stage AD patient V.Y. said, "Ayna varım, büyük bir aynam" (tried to say, "I have a mirror, a big mirror," but used first-person singular instead of third-person singular). $3^{\text {rd }}$ stage $A D$ patient F.Ç. said "Allaha şükür. Onu hiçbir şeye sıkılmadı bu zamana kadar" (tries to say "Thanks God. I haven't had any problems until now" but used passive voice with direct object and wrong subject).

\subsection{Inability to Explain the Working Principles of Tools and Equipment}

No disorder of this kind was observed in $1^{\text {st }}$ stage AD patients participating in the study. When asked, "How do you think this clock works?" $2^{\text {nd }}$ stage AD patient P.S., answered, "This shows what time is it, there with these hands". When asked, "How do we write on the notebook with this pen?" $3^{\text {rd }}$ stage AD patient S.M. replied, "This is what does it in a book or a notebook, a pen, now whatever is there of course".

\section{DISCUSSION}

$A D$ is a progressive neurodegenerative disease, characterized by semantic degradation caused by the aggressive course of cortical atrophy. This degradation results in the impairment of patients' pragmatic functions, representing the most complex component of language. Literature review shows that there are few studies in the field of language and speech therapy in Turkey, especially those dealing with pragmatic language disorders. In order to fill this gap, it is crucial to identify pragmatic language disorders caused by semantic degradation, as recent studies reveal that some types of dementia can be reversed by early diagnosis (27). Since one of the early symptoms of the disease is the deterioration in the ability to use language, this study is important in terms of detecting the disease at an early stage and allowing to start the medical intervention much earlier.

As a result of the study, a significant difference was observed in pragmatic language skills of $A D$ patients compared to the control group. After analysing the transcribed texts, a 19-item inventory of pragmatic disorders resulting from semantic degradation experienced by $A D$ patients was developed. The inventory includes such disorders as inability to understand and use abstract language, inability to make up long sentences, repetitions (perseveration and echolalia), inability to follow a thread of conversation, showing lesser tendency for clustering behaviour, being aware of having made a mistake but not being able to correct it, inability to grasp the main idea of the conversation, inability to start a conversation, inability to understand the question asked, lack 
of respectful language usage, frequent use of the word "şey", periphrasis, semantic and neologistic paraphasia, omitting words and predicates in sentences, inability to answer the question properly, speaking out of context, inability to provide information and explanations, inappropriate and incorrect use of subjects and personal endings, and inability to explain the working principles of tools and equipment.

The above-mentioned disorders were found out to differ according to the stages of $A D$ and the demographic characteristics of the patients. It was determined that the early stage of $A D$ is characterised by mild pragmatic disorders, which tend to get more distinct at the middle stage and even more severe at the late stage. In addition, the evidence from this study suggests that patients which have a higher level of education and a daily reading habit and which communicate more with other individuals display lower levels of pragmatic disorders than other patients at the same stage of AD.

The results obtained are consistent with the findings of previous studies. For example, Cuerva et al. examined pragmatic abilities in thirty-four subjects with probable $A D$ and came to the conclusion that $A D$ subjects displayed significantly more severe pragmatic deficits than controls (28). Amanzio et al., Papagno, Rassiga et al., Papagno et al. reported that comprehension of non-literal language in $A D$ patients decreased over time (29-32). Leyhe et al. and Chapman et al. found that $A D$ patients experienced significant difficulty with interpretation of proverbs $(33,34)$. Mentis et al. discussed discourse deficits in $A D$ patients, such as problems with topic management during casual conversational interaction (35). Carlomagno et al. found that $A D$ patients produced confounding and irrelevant information during the communication task (36). Welland et al. reported poorer overall comprehension of narratives in subjects with early-stage and middle-stage AD (37).

\section{Limitations of the Study}

The findings of this study have to be seen in light of some limitations. The primary limitation to the generalization of the results is a small sample size. However, the results of this study provide valuable insight about the types of pragmatic language disorders in AD patients.

\section{CONCLUSION}

The present study confirmed previous findings and contributed additional evidence that suggests that unlike healthy aging elderly people, adults with $A D$ suffer from pragmatic language impairment. It revealed a broad spectrum of pragmatic disorders in AD patients, which were classified into 19 categories. It was determined that the demographic characteristics of the patients as well as their reading habits and quantity of communication have an impact on the severity of the pragmatic language disorders.

\section{REFERENCES}

[1] Gürvit Hí. Demans sendromu, Alzheimer hastalığı ve Alzheimer dışı demanslar. Bahar SZ, Öge EA, editors. Nöroloji. İstanbul: Nobel Tıp Kitabevleri; 2004.p.367-415. (Turkish)

[2] Bayles K, Tomoeda C. Cognitive-Communication Disorders of Dementia. 1st ed. Oxford: Plural Publishing; 2007.

[3] McKhann GM, Knopman DS, Chertkow H, Hyman BT, Jack CR Jr, Kawas CH, Klunk WE, Koroshetz WJ, Manly JJ, Mayeux R, Mohs RC, Morris JC, Rossor MN, Scheltens P, Carrillo MC, Thies $\mathrm{B}$, Weintraub $\mathrm{S}$, Phelps $\mathrm{CH}$. The diagnosis of dementia due to $A D$ disease: Recommendations from the National Institute on Aging-AD Association Workgroups on diagnostic guidelines for AD disease. Alzheimers Dement 2011;7(3):263-269.

[4] Koçer B. Demans epidemiyolojisi. Türk Psikiyatri Dizini: Demans Dizisi 1999;1(2):41-44. (Turkish)

[5] Ferri CP, Prince M, Brayne C, Brodaty H, Fratiglioni L, Ganguli M, Hall K, Hasegawa K, Hendrie H, Huang $Y$, Jorm A, Mathers C, Menezes PR, Rimmer E, Scazufca M, Alzheimer's Disease International. Global prevalence of dementia: a Delphi consensus study. Lancet 2005;366(9503):2112-2117.

[6] Maviş i, Özbabalık D. Yaşlılıkta nörolojik temelli iletişim sorunları ve dil ve konuşma terapisi. Sosyal Bilimler Dergisi 2006;6(1):1-18. (Turkish)

[7] Weintraub S, Mesulam M. With or without FUS, it is the anatomy that dictates the dementia phenotype. Brain 2009;132:2906-2908.

[8] Wilcock GK, Esiri MM. Plaques, tangles and dementia. A quantitative study. J Neurol Sci 1982;56(2-3):343-356.

[9] Ringman JM, Vinters HV. AD and the frontotemporal dementia syndromes. Coffey CE, Cummings JL, editors. The American Psychiatric Publishing Textbook of Geriatric Neuropsychiatry. Arlington: The American Psychiatric Publishing; 2011.p.407425.

[10] Braak H, Alafuzoff I, Arzberger T, Kretzschmar H, Del Tredici K. Staging of Alzheimer disease-associated neurofibrillary pathology using paraffin sections and immunocytochemistry. Acta Neuropathologica 2006;112:389-404.

[11] Yıldırım E. Alzheimer Hastalığında Sosyal Kognitif Becerilerin Dinlenim Durumu Bağlantısallığı ile İlişkisinin İncelenmesi. İstanbul Üniversitesi. Sağlık Bilimleri Enstitüsü, Doktora Tezi. 2018. (Turkish)

[12] Miller E. Language impairment in Alzheimer type dementia. Clinical Psychology Review 1989;9:181-195.

[13] Locassio JJ, Growdon JH, Corkin S. Cognitive test performance in detecting, staging and tracking Alzheimer's disease. Arch Neurol 1995;52(1):1087-1099.

[14] Grossman M, White-Devine T. Sentence comprehension in AD disease. Brain and Languge 1998;62:186-201.

[15] Helmes E, Ostbye T. Beyond memory impairment cognitive changes in Alzheimer's disease. Arch Clin Neuropsychol 2002;17:179-193.

[16] Mesulam MM. Principles of Behavioral and Cognitive Neurology. 2nd ed. New York: Oxford University; 2000.

[17] Öktem Ö. Alzheimer hastalığının erken, orta ve ileri dönemlerinde genel kognitif profil. Karakaş S, Irkeç C, Yüksel N, editors. Beyin ve Nöropsikoloji. Ankara: Çizgi Tıp Yayınevi; 2003.p.101-111. (Turkish)

[18] Can H, Karakaş S. Bilişsel süreçlerde Alzheimer tipi demansa bağlı değişiklikler. Klinik Psikiyatri 2005;8(1):39-41. (Turkish) 
[19] Tonkovich J. Managing long-term communication and memory consequences of dementia. Neurophsiology and Neurogenic Speech and Language Disorders 1995;9(5):9-14.

[20] Martin A. Semantic knowledge in patients with Alzheimer's disease: evidence for degraded representation. Backman $L$, editor. Memory functioning in dementia. Amsterdam: Elsevier Publishers; 1992:p.119-134.

[21] Fleischman DA, Gabrieli JD. Long term memory in Alzheimer's disease. Curr Opin Neurobiol 1999;9:240-244.

[22] March E, Wales R, Pattison P. Language use in normal ageing and dementia of the AD type. Clinical Psychologist 2003;7:300328.

[23] Williams VG, Bruce JM, Westervelt HJ, Davis JD, Grace J, Malloy $P F$, Tremont $G$. Boston naming performance distinguishes between Lewy body and $A D$ dementias. Archives of Clinical Neuropsychology 2007;22:925-931.

[24] Visch-Brink EG, Hagelstein M, Middelkoop HAM, van der Cammen TMJ. Naming and semantic processing in Alzheimer dementia: A coherent picture. Brain and Language 2004;91:1112.

[25] Chapman SB, Highley AP, Thopmson JL. Discourse in fluent aphasia and Alzheimer's disease: Linguistic and pragmatic considerations. Journal of Neurolinguistics 1998;11:55-78.

[26] March EG, Wales R, Pattison P. The uses of nouns and deixis in discourse production in AD disease. Journal of Neurolinguistics 2006;19:311-340.

[27] Eker E. Alzheimer hastalığı. Uğur M, Balcıoğlu i, Kocabaşoğlu $\mathrm{N}$, editors. Türkiye'de Sık Karşılaşılan Psikiyatrik Hastalıklar Sempozyum Dizisi; 2008 March 6-7; Istanbul, Turkey. 2008. pp.85-110. (Turkish)

[28] Cuerva AG, Sabe L, Kuzis G, Tiberti C, Dorrego F, Starkstein SE. Theory of mind and pragmatic abilities in dementia.
Neuropsychiatry, Neuropsychology and Behavioural Neurology 2001;14(3):153-158.

[29] Amanzio M, Geminiani G, Leotta D, Cappa S. Metaphor comprehension in Alzheimer's disease: Novelty matters. Brain and Language 2008;107:1-10.

[30] Papagno C. Comprehension of metaphors and idioms in patients with Alzheimer's disease: A longitudinal study. Brain 2001;124:1450-1460.

[31] Rassiga C, Lucchelli F, Crippa F, Papago C. Ambiguous idiom comprehension in Alzheimer's disease. Journal of Clinical and Experimental Neuropsychology 2009;31:402-411.

[32] Papagno C, Lucchelli F, Muggia S, Rizzo S. Idiom comprehension in Alzheimer's disease: The role of the central executive. Brain 2003;126:2419-2430.

[33] Leyhe T, Saur R, Eschweiler GW, Milian M. Impairment in proverb interpretation as an executive function deficit in patients with amnestic mild cognitive impairment and early Alzheimer's disease. Dementia and Geriatric Cognitive Disorders Extra 2011;1:51-61.

[34] Chapman SB, Highley AP, Thompson JL. Discourse in fluent aphasia and Alzheimer's disease: Linguistic and pragmatic considerations. Journal of Neurolinguistics 1998;11:55-78.

[35] [35] Mentis M, Briggs-Whittaker J, Gramigna GD. Discourse topic management in senile dementia of the Alzheimer's type. Journal of Speech and Hearing Research 1995;38:1054-1066.

[36] Carlomagno S, Santoro A, Menditti A, Pandolfi M, Marini A. Referential communication in Alzheimer's type dementia. Cortex 2005;41(4):520-534.

[37] Welland RJ, Lubinski R, Higginbotham DJ. Discourse comprehension test performance of elders with dementia of the Alzheimer type. Journal of Speech, Language, and Hearing Research 2002;45:1175-1187.

How to cite this article: Sakin B. Pragmatic Language Disorders Resulting from Semantic Degradation in Patients with Alzheimer's Disease. Clin Exp Health Sci 2021; 11: 523-528. DOI: 10.33808/clinexphealthsci.840917 